boundary marches with the Forestry Commission's Kielder Forest, and this forest and the adjoining ones of Kershope in Cumberland and Newcastleton and Wauchope in Roxburghshire have been declared a national forest park, to be known as the Border Forest Park, by the Forestry Commission. The forest plantations will be opened to the public as soon as is practicable; in some cases this stage has already been reached, but new plantations will have to be protected for a number of years to come. The Brecon Beacons National Park, which comprises a total area of approximately 515 square miles, lying within the counties of Brecon, Carmarthen and Monmouth, is the third such park in Wales. It is one of the lesserknown of Britain's mountain areas, but none the less contains some of the finest scenery of South Wales, and indeed of Great Britain. The River Usk offers some of the finest salmon-fishing outside Scotland, and there is also fishing in the Llangorse Lake under the shadow of the Black Mountains, where many varieties of wild fowl are to be found. Some old and interesting towns lie within the park, including Brecon itself with its cathedral and the once-walled market town of Hay-on-Wye ; sites of Roman and ancient British settlements abound, and there are several fine Norman and medieval castles, interesting churches and country houses.

\section{Research in the Belgian Congo}

WorkERs at the Institute for Scientific Research in Central Africa, Bukavu, Belgian Congo, have produced more than three hundred and fifty original papers in the biological, social and physical sciences since 1948. Those directing the policy of the Institute decided at the outset not to publish a special journal, but to send their contributions to recognized periodicals, usually in Belgium although, where appropriate, in other countries also. They felt that a separate journal would contain too diverse a collection of papers to be generally useful and might tend to isolate the workers at the Institute, already geographically at something of a disadvantage, from their fellow scientists in other countries. The Institute has now started to issue quarterly its Folia Scientifica Africae Centralis (1, No. 1; 1955). This is not intended to compete with existing publications, but to supplement them and at the same time to make it easier for readers to grasp the scope of the work of the Institute. Four reasons for producing this publication are given. First, it will contain reports on the current programmes of the different sections, written in French and Flemish with a summary in English. Secondly, brief preliminary notes on new discoveries will be printed in French and English. Thirdly, there will be résumés in English of some of the more important papers by workers at the Institute appearing in Belgian and foreign journals. Finally, there will be annual lists of titles of new papers; the first number has a supplement of 360 titles, covering the period from 1948 to December 1954.

Centro Appenninico, Terminillo: Biological Research Station in the Apennines

Some years ago the Italian National Research Council, at the instigation of Prof. Carlo Jucci, professor of zoology in the University of Pavia, decided to set up on Mount Terminillo, in the Apennines, a biological research station concerned with the pure and applied aspects of agricultural science, especially in their relation to the mountains (see Nature, 163, 811 ; 1949). This station, known as the Centro
Appenninico, Terminillo, was formally inaugurated in August last year, and its work is now in full swing. It is situated in Terminillo, a village on the middle slopes of the mountain of the same name, which is a winter sports and also a summer resort, and for this reason enjoys good road communications, the bus trip from Rome, via Rieti, taking about three hours. The station stands on sloping grassland at $5,700 \mathrm{ft}$. $(1,730 \mathrm{~m}$.) at the lower limit of the zone of subalpine vegetation which extends to the top of the

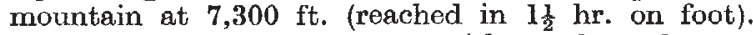
The winter climate is severe, with patches of snow still remaining on the mountain as late as May. The summer is never unduly hot but usually very dry, the rainfall being largely confined to the winter months. The Centre includes a meteorological station.

Cultivated plots for research purposes (mostly terraced owing to the steep slopes) are available close to the station itself, and also at $3,500 \mathrm{ft}$. half-way down to the plain; arrangements are being made for the use of a plot on the plain itself (about 1,200 ft.). There are six small laboratories equipped for standard work in microbiology, biochemistry, entomology, agrarian genetics, cryptogamic botany, cytogenetics and also physics. There are also a small museum and library. Board and lodging are available on the premisos. The works so far undertaken at the Centre has boen mainly concerned with the genetical study, and the improvement by selection for mountain environments, of crops which are important, or potentially important, to a hill populationespecially the potato and the tomato. Hill pasture improvement has also been studied, and, as a minor mountain industry, the cultivation of medicinal herbs. It is hoped that the Centre will in time become well onough known abroad to attract numerous foreign workers in a much wider range of scientific activities, and assume an increasingly international character. Already a number of scientific meetings have been held there. Those interested in the Centre should write to the director, Prof. Carlo Jucci, at the Istituto di Zoologia della Università, Palazzo Botta, Pavia.

\section{World Power Conference: Report for 1954}

The annual report for 1954 of the World Power Conference (pp. 17. London: World Power Conference, 1955) records the admission to membership of Paraguay, Spain and Thailand at the July 1954 meeting of the International Executive Council, bringing the membership to forty-three. The Brazilian Sectional Meeting of the Conference was held at Petrópolis, Rio de Janeiro, during July 25-31, 1954, being attended by 522 members from thirty-four countries, and the bound transactions were due for publication this year. The fifth World Power Conference will be held in Vienna during June 15-23, 1956, and a surnmary of the technical programme is appended to the report. "Statistical Year-book No. 7 " of the Conference was published in July 1954, and the usual list of publications issued, or to be issued, under the auspices of the International Executive Council is also appended to the report, which includes a noto on the twenty-first executive meeting of the International Commission on Large Dams of the World Power Conference. A new edition of the "List of National Committees and Representatives" was published in June, and the British National Committee has issued a list of twenty-six papers to be presented at the Fifth World Power Conference : these include three dealing with nuclear 